\title{
Suitability of Green Gram Production in Kenya under Present and Future Climate Scenarios Using Bias-Corrected Cordex RCA4 Models
}

\author{
Jane Wangui Mugo1,2* ${ }^{\infty}$, Franklin J. Opijah², Joshua Ngaina1,2, Faith Karanja3 ${ }^{3}$, Mary Mburu ${ }^{4}$ \\ ${ }^{1}$ Department of Meteorology, South Eastern Kenya University, Kwa Vonza, Kenya \\ ${ }^{2}$ Department of Meteorology, University of Nairobi, Nairobi, Kenya \\ ${ }^{3}$ Department of Geospatial and Space Technology, University of Nairobi, Nairobi, Kenya \\ ${ }^{4}$ Department of Agriculture and Veterinary Sciences, South Eastern Kenya University, Kwa Vonza, Kenya \\ Email: ‘jmugo@seku.ac.ke, jannymugo@gmail.com
}

How to cite this paper: Mugo, J.W., Opijah, F.J., Ngaina, J., Karanja, F. and Mburu, M. (2020) Suitability of Green Gram Production in Kenya under Present and Future Climate Scenarios Using Bias-Corrected Cordex RCA4 Models. Agricultural Sciences, 11, 882-896.

https://doi.org/10.4236/as.2020.1110057

Received: September 9, 2020

Accepted: October 10, 2020

Published: October 13, 2020

Copyright $\odot 2020$ by author(s) and Scientific Research Publishing Inc. This work is licensed under the Creative Commons Attribution International License (CC BY 4.0).

http://creativecommons.org/licenses/by/4.0/ (c) (i) Open Access

\begin{abstract}
Green gram is considered as one of the legumes suitable for cultivation in the Arid and Semi-Arid Lands (ASALs) of Kenya. However, climate change may alter the areas suitable for green gram production. This study sought to model green gram suitability in Kenya under present and future conditions using bias-corrected RCA4 models data. The datasets used were: maps of soil parameters extracted from Kenya Soil Survey map; present and future rainfall and temperature data from an ensemble of nine models from the Fourth Edition of the Rossby Centre (RCA4) Regional Climate Model (RCM); and altitude from the Digital elevation model (DEM) of the USGS. The maps were first reclassified into four classes of suitability as Highly Suitable (S1), Moderately Suitable (S2), Marginally Suitable (S3), and Not Suitable (N). The classes represent the different levels of influence of a factor on the growth and yield of green grams. The reclassified maps were then assigned a weight generated using the Analytical Hierarchy Process (AHP). A weighted overlay of climate characteristics (past and future rainfall and temperature), soil properties (depth, $\mathrm{pH}$, texture, CEC, and drainage) and altitude found most of Kenya as moderately suitable for green gram production during the March to May (MAM) and October to December (OND) seasons under the baseline, RCP 4.5 and RCP 8.5 scenarios with highly suitable areas being found in Counties like Kitui, Makueni, and West Pokot among others. During the MAM season, the area currently highly suitable for green gram production $\left(67,842.62 \mathrm{~km}^{2}\right)$ will increase slightly to $68,600.4 \mathrm{~km}^{2}(1.1 \%)$ during the RCP 4.5 and reduce to $61,307.8 \mathrm{~km}^{2}(-9.6 \%)$ under the RCP 8.5 scenario. During the OND season, the area currently highly suitable $\left(49,633.4 \mathrm{~km}^{2}\right)$ will increase under both RCP 4.5 (22.2\%) and RCP 8.5 (58.5\%) scenarios. This in-
\end{abstract}


crease is as a result of favourable rainfall and temperature conditions in the future.

\section{Keywords}

Climate Change, Green Gram, Kenya, Rainfall, Soil, Suitability, Temperature, Topography

\section{Introduction}

Over $80 \%$ of Kenyan land is classified as ASALs and is considered as being the most susceptible to the effects of climate change and variability [1]. The ASAL regions of Kenya are characterised by low rainfall that varies in space and time. These areas also experience prolonged dry seasons with high evapotranspiration rates [1]. Climate in its spatial and temporal variability is one of the major drivers determining agricultural productivity in a region.

There is general agreement that climate is changing, and that the agricultural sector among others will be affected under future climates. Climate change may have an impact on both the ASAL and high potential areas in Kenya making present agricultural use unsuitable. Climate-smart agriculture either by growing drought-resistant crops or supplementing rainfall with irrigation can help the country generate income, employment, and attain food security. To develop long-term agricultural policies, planners need to understand the likely impacts of climate change on agricultural suitability zones [2].

Green gram (Vigna radiata L.), is a short duration (65 - 90 days) grain legume grown on more than 6 million hectares globally in the warm areas [3] [4]. Green gram is native to the Indian subcontinent [4], but also grown in the dry and hot regions of Eastern Africa, Southern Europe and Southern United States [5], and reported to have spread early into other Asian countries and to northern Africa. India is the largest consumer and producer of green grams, accounting for $54 \%$ and $65 \%$ of world consumption and acreage respectively.

Green gram is considered as a legume suitable for cultivation in the ASALs due to its ability to perform well under the dry conditions found in the semi-arid regions [6]. Since green gram performs well in dry conditions, with this dryness expected to worsen with future climate change, green gram may be a better crop for subsistence farmers to survive the expected effects of climate change. Planting green grams where it is best suited will bring more returns to farmers, enhance food security, and increase food production [7]. To enhance the productivity of green grams, there is need to develop a suitability map.

Crop suitability analysis helps determine which areas are currently suitable and whether they will remain so in the future, which is critical for policy regarding the future [8]. Ahmed and Fayyaz-Ul-Hassana [9] recommended using suitability ratings to rank crop production potential based on different ranges in 
the climate, terrain, and soil of the land. Decision-makers are usually engaged to determine which factors they consider most important for suitability analysis using Multiple Criteria Decision Analysis (MCDA); the results are then used in GIS as weights for the suitability analysis. The Analytical Hierarchy Process (AHP) is the most used MCDA method to weigh the factors that decision-makers consider most important for suitability analysis [7]. Several studies have carried research on crop suitability for various crops using the AHP method [7] [10] [11] [12] [13].

Mugo et al. [14] found some areas in Kitui County, an ASAL region in Kenya, suitable for production in terms of climate. There is, however, a lack of knowledge on whether other ASAL areas in Kenya are currently suitable for green gram production, and how climate change will affect their current suitability. This study used a bias corrected multimodel ensemble of rainfall and the multimodel ensemble of mean temperature to carry out the analysis. The process of bias correcting the rainfall data is described in a previous paper by Mugo et al. [15]. This study shall determine which areas in the ASAL regions in Kenya would best support green gram production under baseline (1971-2000) and future (2021-2050) climate conditions for the Representative Concentration Pathways (RCP) 4.5 and 8.5 .

\section{Materials and Methods}

\subsection{Study Area}

Kenya (Figure 1) lies between latitudes $5^{\circ} \mathrm{N}$ and $5^{\circ} \mathrm{S}$ and longitudes $34^{\circ} \mathrm{E}$ and $42^{\circ} \mathrm{E}$ and has an area of approximately $584,000 \mathrm{~km}^{2}$. Kenya's rainfall and temperature pattern is mainly bimodal and is controlled by the location of the Inter-Tropical Convergence Zone (ITCZ). The seasonal migration of the sun which is overhead the equator in March and September and the position of the ITCZ affect the rainfall pattern observed from May to May (MAM) and October to December (OND). The cloud cover influences the observed temperature by lessening the incoming solar radiation and outgoing terrestrial radiation.

Kenya's climate is also affected by its varying topography and the presence of large water bodies. Kenya's elevation increases from the coastal plateau toward central Kenya where Mount Kenya is located. The presence of Mount Elgon and Mount Kilimanjaro put the western part of the country at a higher elevation compared to the eastern part. Large water bodies include the Indian Ocean in the east and Lake Victoria in the west. Rainfall in Kenya has high variability across different regions, with the ASALS experiencing the highest variability in time and space.

The ASALs which make up $80 \%$ of Kenya's total landmass are characterised by high poverty levels, low illiteracy levels, human conflict, poor infrastructure, and land degradation [16]. The ASALs are also prone to floods; despite receiving low levels of rainfall of $300-500 \mathrm{~mm}$ annually [1]. Periods of intensive rainfall have been observed to follow the droughts [17]. However, despite the challenges 
mentioned, the ASALs are rich in natural resources amid them being wildlife, biodiversity, minerals, and diverse culture [16].

\subsection{Data Description}

Secondary digital databases were acquired from various sources as shown in (Table 1). The secondary databases were: maps of soil parameters extracted from Kenya Soil Survey map; present and future rainfall and temperature data from a bias corrected ensemble of nine RCA4 models from the Fourth Edition of the Rossby Centre (RCA4) Regional Climate Model (RCM) [18]; and altitude from the Digital elevation model (DEM) of the USGS.

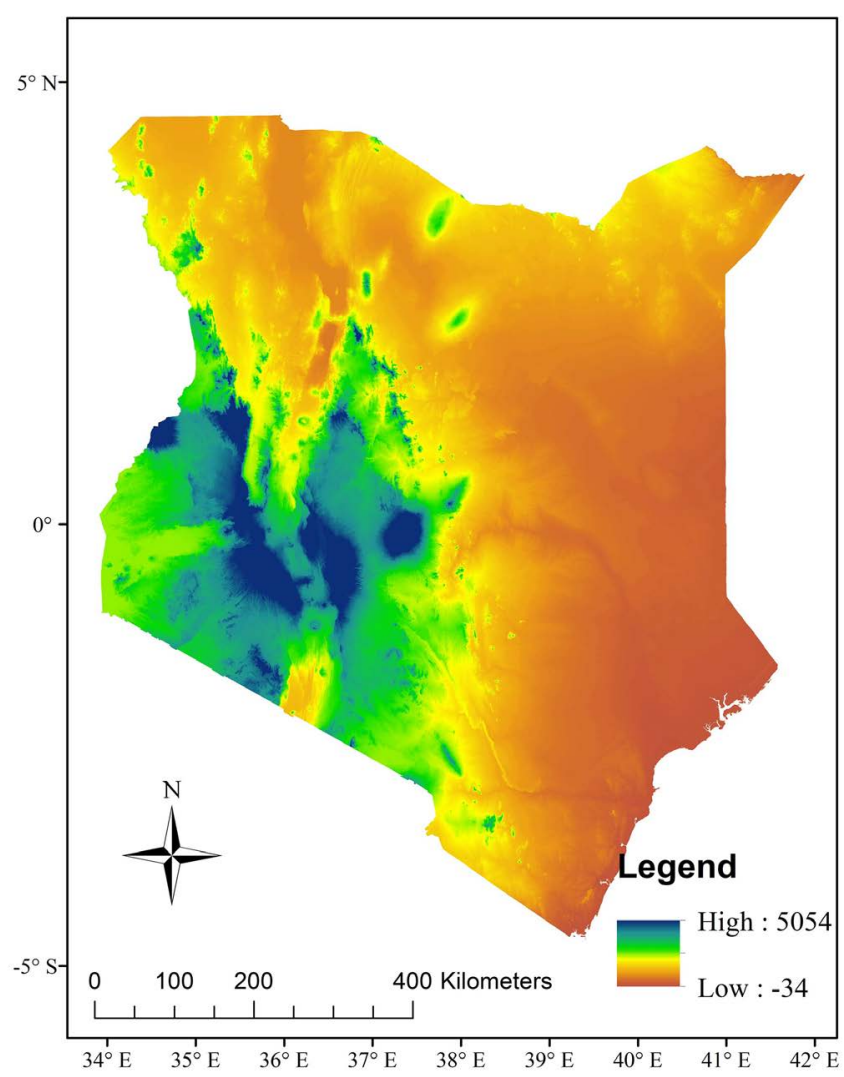

Figure 1. Topography of the study area (in meters). The blue regions show areas of high elevation decreasing through to the brown regions.

Table 1. Description of secondary data sources used as map layers in delineating areas suitable for green gram production.

\begin{tabular}{llll}
\hline Data layer & Source & Scale/Resolution & Data Format \\
\hline $\begin{array}{l}\text { Climate: Temperature } \\
\text { and rainfall }\end{array}$ & CORDEX RCA4 model & 0.44 degrees $/ 50 \mathrm{~km} \begin{array}{l}\text { NETCDF format and } \\
\text { converted to Raster format }\end{array}$ \\
$\begin{array}{l}\text { Soil: pH, CEC, depth, } \\
\text { drainage, and texture }\end{array}$ & Kenya Soils Survey & Vector format and \\
$\begin{array}{l}\text { Topography/DEM: } \\
\text { Altitude }\end{array}$ & $\begin{array}{l}\text { United States Geological } \\
\text { converted to Raster format }\end{array}$ & Roster format \\
\hline
\end{tabular}




\subsection{Methodology}

\subsubsection{Suitability Criteria Assignment and Reclassification of Data}

The data on climatic, soil, and altitude was first categorized into two classes, suitable and not suitable. The two classes were further divided into four classes namely, Highly suitable (S1), Moderately suitable (S2), Marginally suitable (S3), and not suitable $(\mathrm{N})$ as guided by Table 2. Table 3 shows the four classes of suitability in terms of green gram production. The classes represent the different levels of influence of a factor on the growth and yield of green grams.

Table 2. Land suitability classification structure source: [19].

\begin{tabular}{|c|c|c|}
\hline Order & Class & Description \\
\hline \multirow{3}{*}{ S } & S1 & $\begin{array}{l}\text { Land that has no significant limitations to the continued application of a given } \\
\text { use, or only minor limitations that will not remarkably reduce productivity and } \\
\text { benefits and will not raise inputs above an acceptable level. }\end{array}$ \\
\hline & S2 & $\begin{array}{l}\text { Land having limitations which in total are moderately severe for continued } \\
\text { application of a given use; the limitations will thus lower the productivity or } \\
\text { benefits and increase the inputs required to the level that the final advantage } \\
\text { to be obtained from the use, although still attractive, is considerably lower to that } \\
\text { expected on Class S1 land. }\end{array}$ \\
\hline & S3 & $\begin{array}{l}\text { Land having limitations which in total are severe for continued application of a } \\
\text { given use and will so lower productivity and benefits, or increase required inputs, } \\
\text { such that this expenditure is only marginally justifiable. }\end{array}$ \\
\hline \multirow[t]{2}{*}{$\mathrm{N}$} & N1 & $\begin{array}{l}\text { Land having limitations that may be overcome in time but which cannot be } \\
\text { rectified with existing knowledge at a currently acceptable cost, the limitations } \\
\text { are so acute as to prevent the successful sustained use of the land in the given } \\
\text { manner. }\end{array}$ \\
\hline & $\mathrm{N} 2$ & $\begin{array}{l}\text { Land that has limitations which seem to be so severe as to surpass any chance of } \\
\text { successful sustained use of the land in the given manner }\end{array}$ \\
\hline
\end{tabular}

Table 3. Suitability levels for factors used in developing suitable areas for green gram production.

\begin{tabular}{|c|c|c|c|c|c|}
\hline & S1 & S2 & S3 & $\mathrm{N}$ & Source \\
\hline Rainfall & $250-350 \mathrm{~mm}$ & $\begin{array}{l}150-250 \mathrm{~mm} \\
350-600 \mathrm{~mm}\end{array}$ & $\begin{array}{l}75-150 \mathrm{~mm} \\
>600\end{array}$ & $<75 \mathrm{~mm}$ & [20] \\
\hline Temperature & $30^{\circ} \mathrm{C}-21^{\circ} \mathrm{C}$ & $18^{\circ} \mathrm{C}-21^{\circ} \mathrm{C}$ & $15^{\circ} \mathrm{C}-18^{\circ} \mathrm{C}$ & $\begin{array}{l}<15^{\circ} \mathrm{C} \\
>30^{\circ} \mathrm{C}\end{array}$ & [21] \\
\hline Soil pH & $6.2-7.2$ & $5-6.2$ & $7.2-8.0$ & $\begin{array}{l}>8.0 \\
<5.0\end{array}$ & [14] [22] \\
\hline Drainage & Well-drained & $\begin{array}{l}\text { Imperfectly } \\
\text { drained }\end{array}$ & $\begin{array}{l}\text { Poorly drained, } \\
\text { Rapidly drained }\end{array}$ & $\begin{array}{l}\text { Very poorly } \\
\text { drained }\end{array}$ & [14] [23] \\
\hline Texture & $\begin{array}{l}\text { Loam } \\
\text { Sandy Loam }\end{array}$ & Clayey & $\begin{array}{l}\text { Very clayey } \\
\text { Extremely sandy }\end{array}$ & - & [14] [23] \\
\hline CEC & $>10 \mathrm{meq} / 100 \mathrm{~g}$ & $5-10 \mathrm{meq} / 100 \mathrm{~g}$ & $0-5 \mathrm{meq} / 100 \mathrm{~g}$ & - & {$[14][22]$} \\
\hline Depth & $>50 \mathrm{~cm}$ & $30-50 \mathrm{~cm}$ & $<30 \mathrm{~cm}$ & & [14] [23] \\
\hline Altitude & $0-1600 m$ & $1600-2000 m$ & - & $\begin{array}{l}>2000 \mathrm{~m} \\
<0 \mathrm{~m}\end{array}$ & [14] [22] \\
\hline
\end{tabular}




\subsubsection{Factor Weight Assignment Using the Analytical Hierarchy Process}

A scale of values from 1 to 9 (Table 4) was used to compare and assign weights to factors [24] under climate (rainfall and temperature), soil (depth, pH, texture, CEC, and drainage) and altitude.

A Consistency Ratio (CR) (Equation (1)) was determined and for the weights to be accepted, the ratio was expected to be less than $10 \%$ to prevent bias [8].

$$
\begin{gathered}
C R=\frac{C I}{R I} \\
C I=\frac{(\lambda \max -n)}{(n-1)}
\end{gathered}
$$

In Equation (1) $C R$ represents the Consistency Ratio and $R I$ stands for the Random Inconsistency Index which is dependent on the number of factors being related as shown in (Table 5). In Equation (2) CI signifies the Consistency Index; $\lambda$ max represents the maximum Eigenvalue of the pairwise comparisons, and $n$ counts the number of factors being related.

\subsubsection{Green Gram Suitability Map}

After reclassifying the criteria maps, each was assigned a certain percentage stake (weight). These were the weights obtained through the analytical hierarchy process. The maps were then overlaid to generate the final output which is a green gram suitability map under baseline (1971-2000) and future (2021-2050) RCP 4.5 and 8.5 climate conditions.

\section{Results and Discussions}

\subsection{Analysis of the Suitability of Land for Green Gram Production under Past and Future Climate Scenarios}

This section presents results obtained from the weighted overlay of climate (past and future rainfall and temperature), soil (depth, $\mathrm{pH}$, texture, CEC, and drainage), and altitude. The first step in analysing the suitability of green gram production involved reclassification of soil and climate parameters.

Table 4. Scale of relative importance between any two factors which affect green gram production e.g. rainfall vs. drainage.

\begin{tabular}{lc}
\hline Definition of Importance & Scale \\
\hline Factors have equal rank & 1 \\
One factor has weak rank over the other & 3 \\
One factor has strong rank over the other & 5 \\
One factor has demonstrated importance over the other & 7 \\
One factor has absolute rank over the other & 9 \\
Intermediate values used when factor importance lies between the odd numbers & $2,4,6,8$
\end{tabular}


Table 5. Random Inconsistency Index (RI) for $\mathrm{N}=1,2 \ldots, 11$.

\begin{tabular}{cccccccccccc}
\hline $\mathrm{N}$ & I & II & III & IV & V & VI & VII & VII & IX & X & XI \\
\hline RI & 0.00 & 0.00 & 0.58 & 0.90 & 1.12 & 1.24 & 1.32 & 1.41 & 1.45 & 1.49 & 1.51 \\
\hline Source: [24].
\end{tabular}

\subsubsection{Reclassification of Soil and Altitude Parameters in Terms of Their Suitability for Green Gram Production}

This subsection presents the results on the reclassification of soil and altitude depending on their suitability levels (Table 2). Figure 2 presents the results for the reclassification of soil and altitude parameters into four classes (S1, S2, S3, and N). In Figure 2 factors highly limiting the suitability of green gram were $\mathrm{pH}$, depth, altitude, and drainage.

The $\mathrm{pH}$-water is used as an index of soil suitability for crops or plants; areas not suitable can be improved through liming which can improve the overall suitability. Green gram is well adapted to a $\mathrm{pH}$ range of 5 to 8 [5] [25] [26]. The performance is best on soils with a pH between 6.2 and 7.2 and plants can show serious iron chlorosis symptoms and micronutrient deficiencies on alkaline soils [27]. They require slightly acid soil for the best growth [27].

Soil depth is the estimated space in centimeters where root growth is unrestricted by any physical or chemical impediment such as impenetrable or toxic layer. Areas with poor drainage can be improved upon by building fallows to improve drainage during the rainy season which can further improve suitability.

\subsubsection{Reclassification of Climate Parameters (Temperature and Rainfall) Under Present and Future (RCP 4.5 and RCP 8.5) (2021 to 2050) Scenarios in Terms of Their Suitability for Green Gram Production}

This subsection presents the results of the reclassification of temperature and rainfall depending on their suitability levels (Table 2 ) under the present and future (RCP 4.5 and RCP 8.5) (2021 to 2050) scenarios in terms of their suitability for green gram production.

According to Figure 3, most of Kenya is highly suitable for green gram production in terms of temperature. Areas that are not suitable are noted in Nyeri and Nyandarua Counties since these areas experience temperatures lower than $15^{\circ} \mathrm{C}$ which according to Al-Mashreki et al. [21] are not suitable for green gram production. Under both the RCP 4.5 and RCP 8.5 scenarios during the MAM season, areas around the Northern and Western parts of Kenya will not be suitable for green gram production since they will experience temperatures greater than $30^{\circ} \mathrm{C}$. A temperature range of $28^{\circ} \mathrm{C}$ to $30^{\circ} \mathrm{C}$ is considered optimum for seed germination and plant growth [21] [27].

Figure 4 shows the areas in Kenya that are suitable and not suitable for green gram production in terms of rainfall. Areas that are not suitable for production are located around the North-West part of Kenya during the OND season, where rainfall amounts are less than $75 \mathrm{~mm}$ per season. Water stress reduces the rate of uptake of nutrients, flowering, leaf area development, and photosynthesis 
causing yield reduction [3]. An optimum rainfall of $250-350 \mathrm{~mm}$ is considered best for sustained germination [20].

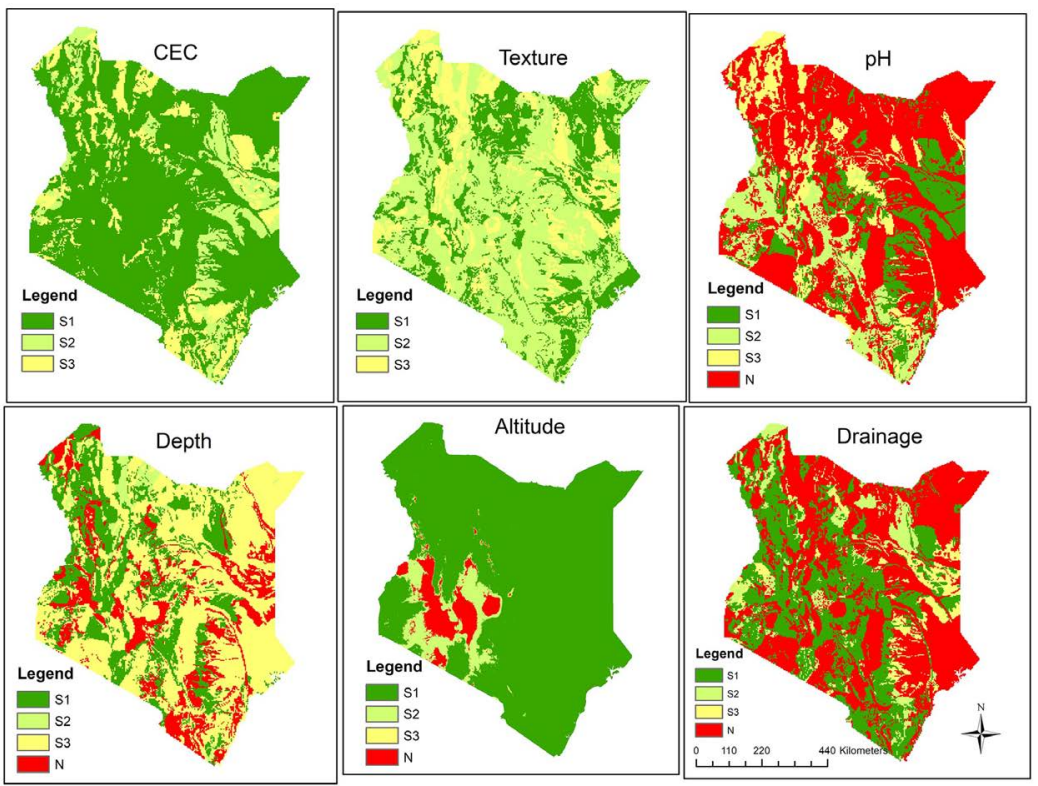

Figure 2. Reclassified maps of soil CEC, texture, $\mathrm{pH}$, depth, altitude, and drainage. The green colour shading (S1) represents the most suitable areas, light green shading (S2) represents the moderately suitable areas, yellow shading (S3) represents the marginally suitable areas, and red shading $(\mathrm{N})$ represents areas that are not suitable for green gram production in Kenya based on these classifications.
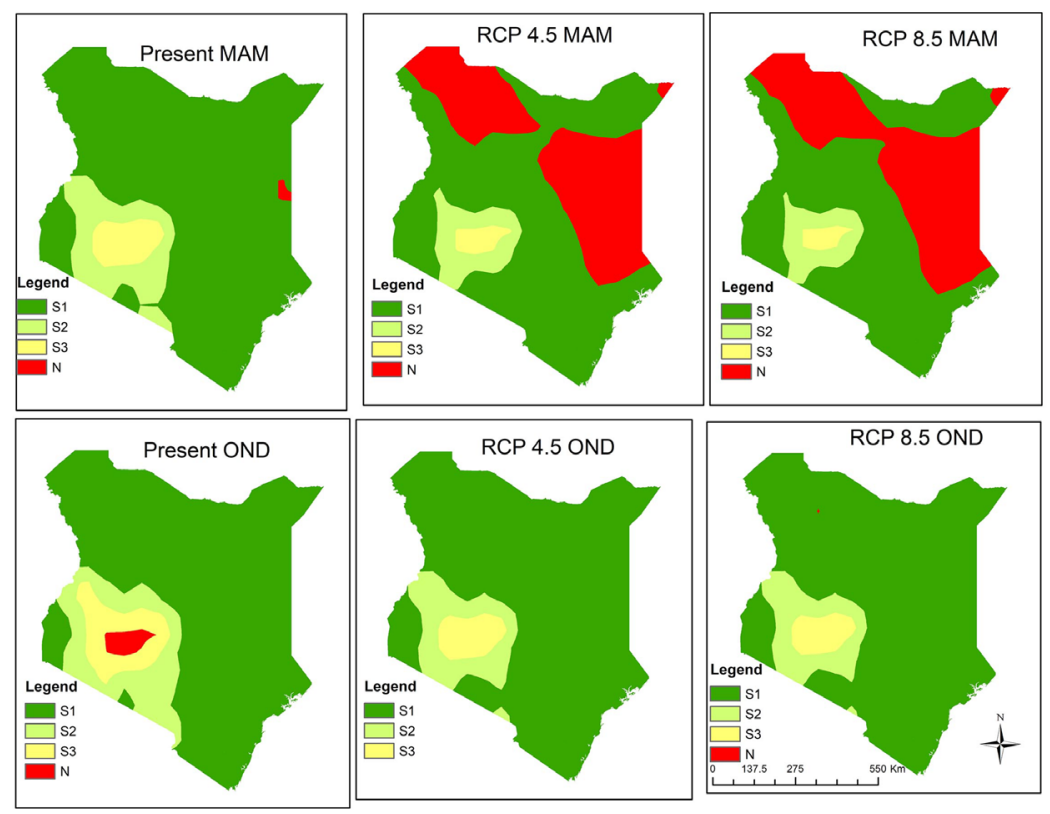

Figure 3. Reclassified maps of present and future mean temperature (in ${ }^{\circ} \mathrm{C}$ ) layers during the MAM and OND seasons. The green colour shading (S1) represents the most suitable areas, light green shading (S2) represents the moderately suitable areas, yellow shading (S3) represents the marginally suitable areas, and red shading $(\mathrm{N})$ represents areas that are not suitable for green gram production in Kenya based on these classifications. 


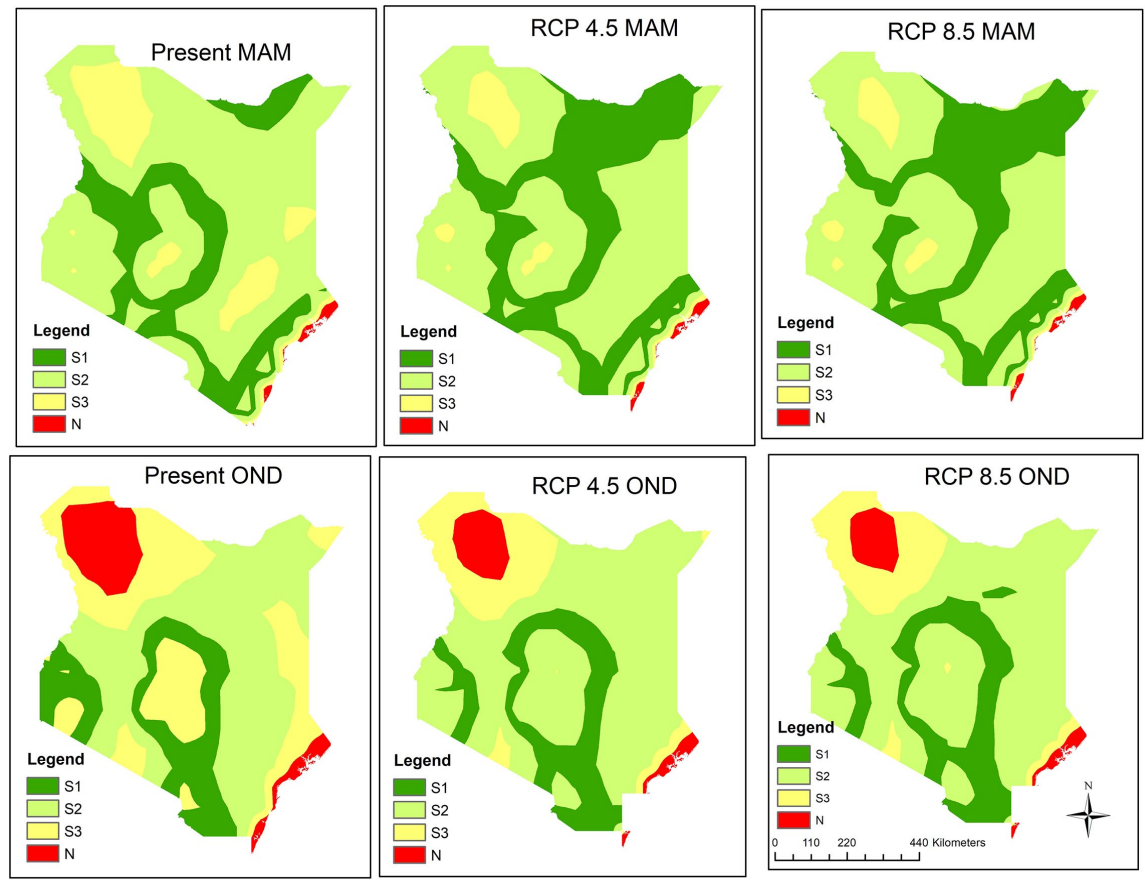

Figure 4. Reclassified maps of present and future total rainfall (in $\mathrm{mm}$ ) during the MAM and OND seasons. The green colour shading (S1) represents the most suitable areas, light green shading (S2) represents the moderately suitable areas, yellow shading (S3) represents the marginally suitable areas, and red shading $(\mathrm{N})$ represents areas that are not suitable for green gram production in Kenya based on these classifications.

\subsubsection{Overall Suitability of Green Gram Production in Kenya Obtained from a Weighted Overlay of Climate (Under Present and Future (RCP 4.5 and RCP 8.5 (2021 to 2050)), Soil and Altitude Parameters}

This subsection presents the results of the green gram suitability maps. The suitability maps were obtained through the weighted overlay of climate, soil, and altitude parameters whose weights were obtained as shown in Table 6.

Figure 5 presents areas suitable for green gram production under historical climate data 1971-2000; Figure 6 presents areas suitable for green gram production in the future under RCP 4.5 scenario for the years 2021 to 2050; Figure 7 presents areas suitable for green gram production under future RCP 8.5 scenario for the years 2021 to 2050 .

Figure 5 (historical), Figure 6 (RCP 4.5), and Figure 7 (RCP 8.5) show that most of the country is currently moderately suitable for green gram production during both the MAM and OND season, with highly suitable classes being found in Counties like Kitui, Machakos, and West Pokot among others.

Table 7 shows the area in $\mathrm{km}^{2}$ suitable for green gram production during the MAM and OND season under baseline and future scenarios. While Table 8 shows the percentage changes between the baseline and the future scenarios. The change in area suitability is only based on climatic parameters and not on the other conditions. 


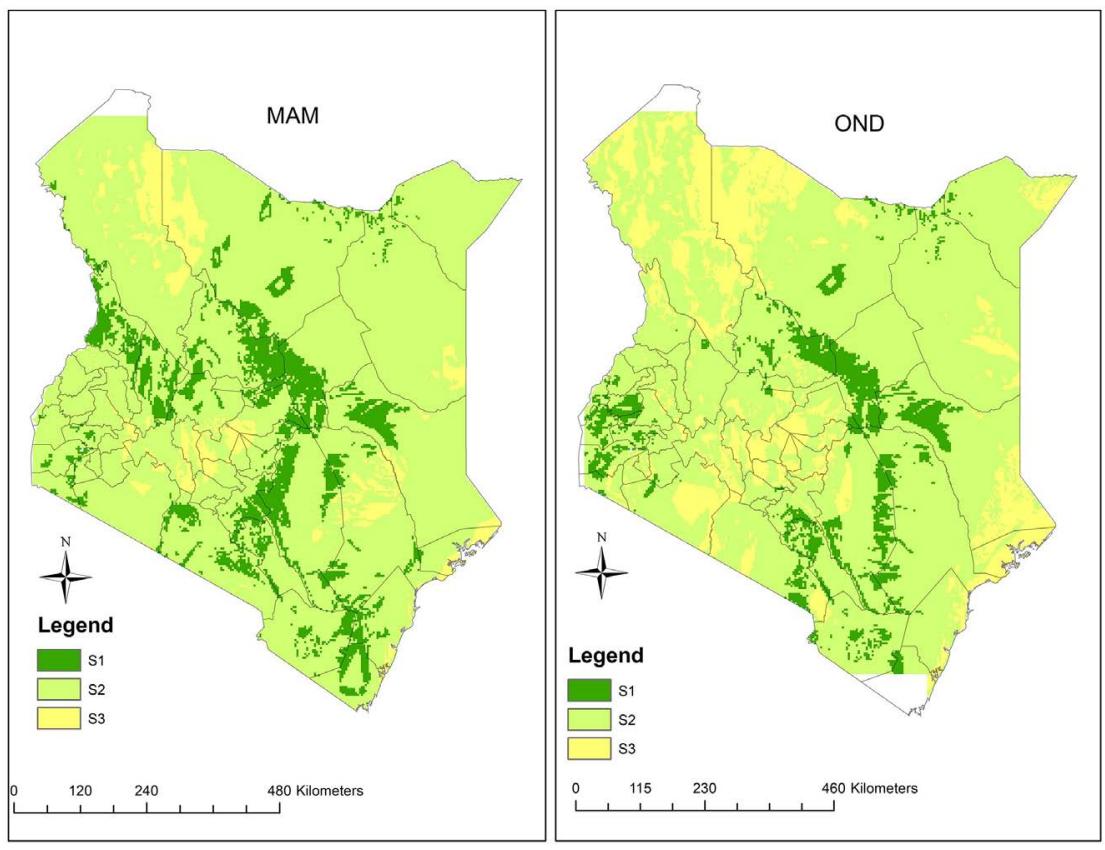

Figure 5. Present lands suitable for green gram production during the MAM and OND season. The green colour shading (S1) represents the most suitable areas, light green shading (S2) represents the moderately suitable areas, yellow shading (S3) represents the marginally suitable areas, and red shading $(\mathrm{N})$ represents areas that are not suitable for green gram production in Kenya based on these classifications.

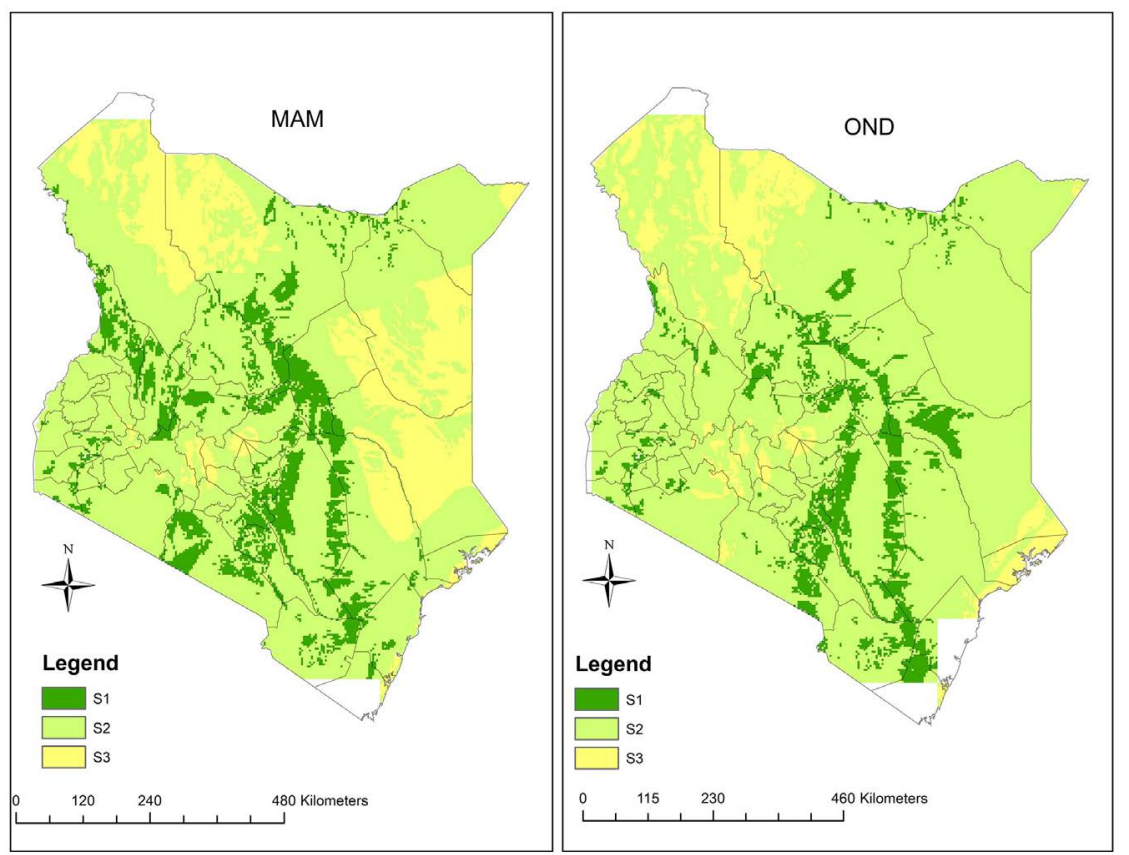

Figure 6. Future land suitable for green gram production during the MAM and OND season under the RCP 4.5 scenario for the years 2021 to 2050. The green shading (S1) represents the most suitable areas, light green shading (S2) represents the moderately suitable areas, yellow shading (S3) represents the marginally suitable areas, and red shading (S4) represents areas that are not suitable for green gram production in Kenya based on these classifications. 

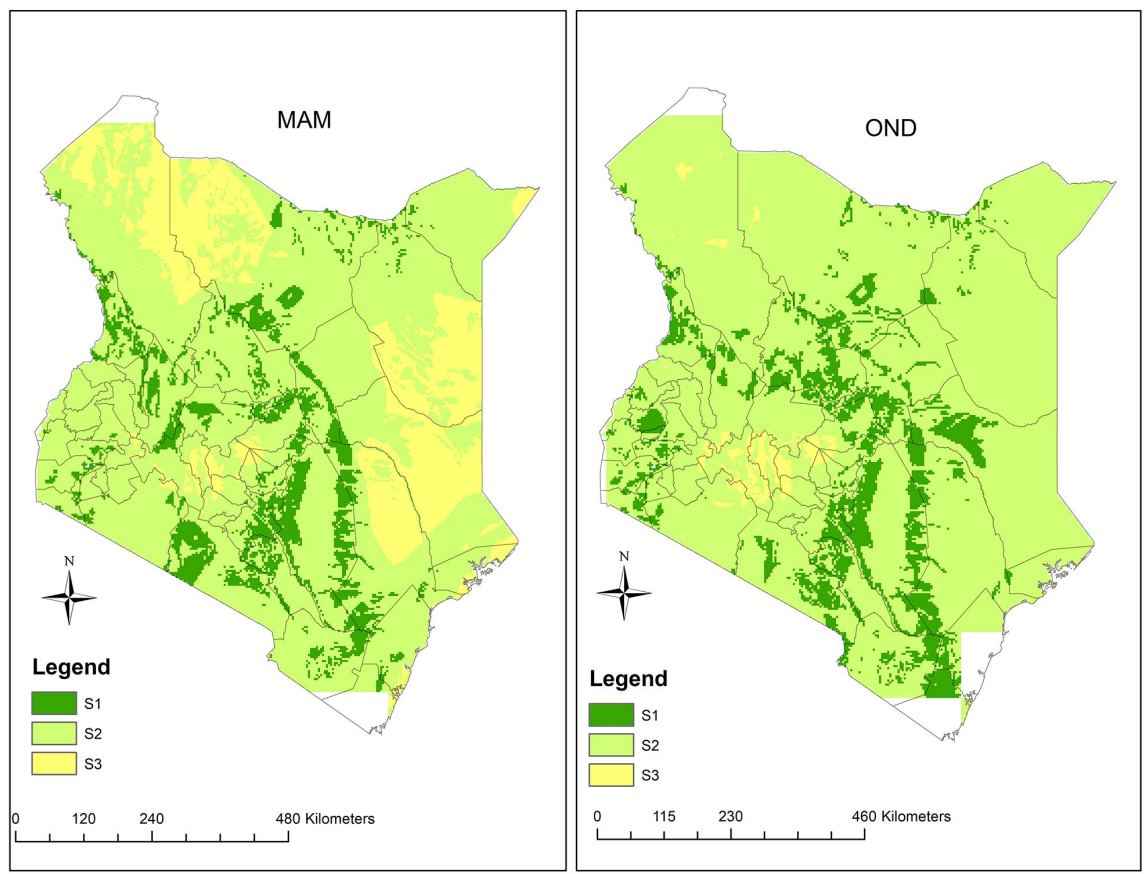

Figure 7. Future land suitable for green gram production during the MAM and OND season under the RCP 8.5 scenario for the years 2021 to 2050. The green colour shading (S1) represents the most suitable areas, light green shading (S2) represents the moderately suitable areas, yellow shading (S3) represents the marginally suitable areas, and red shading $(\mathrm{N})$ represents areas that are not suitable for green gram production in Kenya based on these classifications.

Table 6. Weights obtained through the analytical hierarchy process showing how much each parameter contributes to the weighted overlay of green gram production.

\begin{tabular}{ccccccccccc}
\hline & Rainfall & Temperature & Depth & Texture & CEC & pH & Drainage & Altitude & Weights & Rank \\
\hline Rainfall & 1 & 3.00 & 4.00 & 4.00 & 4.00 & 4.00 & 4.00 & 4.00 & $33.0 \%$ & 1 \\
Temperature & 0.33 & 1 & 3.00 & 3.00 & 3.00 & 3.00 & 3.00 & 3.00 & $20.2 \%$ & 2 \\
Depth & 0.25 & 0.33 & 1 & 2.00 & 0.50 & 0.50 & 0.50 & 2.00 & $6.5 \%$ & 6 \\
Texture & 0.25 & 0.33 & 0.50 & 1 & 0.33 & 0.33 & 0.33 & 2.00 & $5.0 \%$ & 7 \\
CEC & 0.25 & 0.33 & 2.00 & 3.00 & 1 & 1.00 & 0.50 & 2.00 & $9.0 \%$ & 5 \\
pH & 0.25 & 0.33 & 2.00 & 3.00 & 1.00 & 1 & 0.50 & 3.00 & $9.5 \%$ & 4 \\
Drainage & 0.25 & 0.33 & 2.00 & 3.00 & 2.00 & 2.00 & 1 & 3.00 & $12.4 \%$ & 3 \\
Altitude & 0.25 & 0.33 & 0.50 & 0.50 & 0.5 & 0.33 & 0.33 & 1 & $4.3 \%$ & 8 \\
\hline
\end{tabular}

Table 7. Changes in land suitable for green gram production (in $\mathrm{km}^{2}$ ) under historical and future climate scenarios of RCP 4.5 and RCP 8.5 during the MAM and OND seasons.

\begin{tabular}{ccccccc}
\hline & \multicolumn{2}{c}{ HISTORICAL } & \multicolumn{2}{c}{ RCP 4.5} & \multicolumn{2}{c}{ RCP 8.5 } \\
\cline { 2 - 6 } & MAM $\left(\mathbf{k m}^{2}\right)$ & OND $\left(\mathbf{k m}^{2}\right)$ & MAM $\left(\mathbf{k m}^{2}\right)$ & OND $\left(\mathrm{km}^{2}\right)$ & MAM $\left(\mathbf{k m}^{2}\right)$ & OND $\left(\mathrm{km}^{2}\right)$ \\
\hline S1 & $67,842.6$ & $45,729.3$ & $68,600.4$ & $55,885.1$ & $61,307.8$ & $72,464.8$ \\
S2 & 470,972 & $423,463.3$ & $391,768.9$ & $457,128.1$ & $404,721.1$ & $488,043.8$ \\
S3 & $41,552.4$ & $111,174.4$ & $119,997.7$ & $60,173.4$ & $114,275.8$ & $12,777.6$ \\
\hline
\end{tabular}


Table 8. Percentage changes in land suitable for green gram production between historical and future climate scenarios of RCP 4.5 and RCP 8.5 during the MAM and OND seasons.

\begin{tabular}{ccccc}
\hline & & RCP 4.5 & & RCP 8.5 \\
\cline { 2 - 5 } & MAM & OND & MAM & OND \\
\hline S1 & $1.1 \%$ & $22.2 \%$ & $-9.6 \%$ & $58.5 \%$ \\
S2 & $-16.8 \%$ & $7.9 \%$ & $-14.1 \%$ & $15.3 \%$ \\
S3 & $188.8 \%$ & $-45.9 \%$ & $175.0 \%$ & $-88.5 \%$ \\
\hline
\end{tabular}

Currently, 67,842.62 $\mathrm{km}^{2}$ and $45,729.3 \mathrm{~km}^{2}$ are highly suitable for green gram production in Kenya during MAM and OND seasons respectively. The area highly suitable during MAM will increase slightly by $1.1 \%$ to $68,600.4 \mathrm{~km}^{2}$ according to the RCP 4.5 and reduce by $-9.6 \%$ to $61,307.8 \mathrm{~km}^{2}$ under the RCP 8.5 scenario. The area highly suitable during OND will increase by $22.2 \%$ to $55,885.1$ $\mathrm{km}^{2}$ according to the RCP 4.5 and reduce by $-9.6 \%$ to $72,464.8 \mathrm{~km}^{2}$ under the RCP 8.5 scenario. This increase is as a result of favourable rainfall and temperature conditions in the future.

Currently, 470,972 $\mathrm{km}^{2}$ and 423,463.3 $\mathrm{km}^{2}$ are moderately suitable for green gram production in Kenya during MAM and OND seasons respectively. The area moderately suitable during MAM will reduce by $-16.8 \%$ to $391,768.9 \mathrm{~km}^{2}$ according to the RCP 4.5 , and by $-14.1 \%$ to $404,721.1 \mathrm{~km}^{2}$ under the RCP 8.5 scenario. The area moderately suitable during OND will increase by $7.9 \%$ to $457,128.1 \mathrm{~km}^{2}$ according to the RCP 4.5 and by $15.3 \%$ to $488,043.8 \mathrm{~km}^{2}$ under the RCP 8.5 scenario.

Currently, 41,552.4 $\mathrm{km}^{2}$ and $111,174.4 \mathrm{~km}^{2}$ are marginally suitable for green gram production in Kenya during MAM and OND seasons respectively. The area marginally suitable during MAM will increase by $188.8 \%$ to $119,997.7 \mathrm{~km}^{2}$ according to the RCP 4.5 and by $175.0 \%$ to $114,275.8 \mathrm{~km}^{2}$ under the RCP 8.5 scenario. The area marginally suitable during OND will reduce by $-45.9 \%$ to $60,173.4 \mathrm{~km}^{2}$ under the RCP 4.5 and by $-88.5 \%$ to $12,777.6 \mathrm{~km}^{2}$ under the RCP 8.5 scenario.

\section{Conclusions and Recommendations}

This study sought to model green gram suitability in Kenya under changing climate. Maps showing different levels of green gram suitability in Kenya were obtained through a weighted overlay of climate characteristics (past and future rainfall and temperature), soil properties (depth, $\mathrm{pH}$, texture, $\mathrm{CEC}$, and drainage) and altitude parameters. The parameter maps were first classified into four classes: Highly Suitable (S1), Moderately Suitable (S2), Marginally Suitable (S3), and Not Suitable $(\mathrm{N})$ in terms of their suitability for green gram production. The analyses showed that there are areas in Kenya that are currently not suitable for green gram production and these limitations prevent the successful sustained use of the land for green gram production. The maps of soil $\mathrm{pH}$, depth, and drainage, and altitude show there are areas in Kenya that are currently not suitable. 
When generating the suitability map for green gram production, the change in suitability was only attributed to climate parameters under past and future scenarios. Land use, physical and chemical properties of the soil, and topography were assumed to remain constant in the future since the model persists the prevailing structures.

The areas that are not suitable for green gram production in terms of the prevailing temperature under present conditions are counties of Nyeri and Nyandarua Counties; this is because these areas experience temperatures lower than $15^{\circ} \mathrm{C}$. The areas in the northern and eastern parts of Kenya will not be suitable for green gram production in the future under both RCP 4.5 and RCP 8.5 scenarios during the MAM season since they will experience temperatures greater than $30^{\circ} \mathrm{C}$ which is not suitable for green gram production. A temperature range of $28^{\circ} \mathrm{C}$ to $30^{\circ} \mathrm{C}$ is considered optimum for seed germination and plant growth.

Rainfall areas that are not suitable for production are located in the north-western part of Kenya during the OND season for all scenarios, since rainfall amounts are less than $75 \mathrm{~mm}$ per season. No areas receive rainfall lower than $75 \mathrm{~mm}$ for all scenarios in the MAM season which would be unsuitable for green gram production. Water stress reduces the rate of uptake of nutrients, flowering, leaf area development, and photosynthesis causing yield reduction. An optimum rainfall of $250-350 \mathrm{~mm}$ is considered best for sustained germination.

Most of Kenya was found moderately suitable for green gram production during the MAM and OND seasons under the baseline, RCP 4.5 and RCP 8.5 scenarios. The area currently highly suitable for green production in Kenya will decrease during the MAM season but increase during the OND season for both RCP 4.5 and RCP 8.5 scenarios. In the highly suitable area for green gram production, players in the green gram value chain should take advantage of the good weather and adequately prepare since a good harvest is highly likely. Adequate preparation includes using the appropriate inputs in terms of seeds, pesticides, and fertilizers which will ensure positive results as the environment is already suitable for cultivation.

\section{Acknowledgements}

This research paper is part of the $\mathrm{PhD}$ thesis for the lead author at the University of Nairobi, Kenya. The authors acknowledge sources of data used as provided by Coordinated Regional Downscaling Experiment (CORDEX), Kenya Soil Survey (KSS) and the United States Geological Survey (USGS). The lead author expresses appreciation to the German Academic Exchange Service (DAAD) scholarship for the financial support.

\section{Conflicts of Interest}

The authors declare no conflicts of interest regarding the publication of this paper. 


\section{References}

[1] Opiyo, F., Wasonga, O., Nyangito, M., Schilling, J. and Munang, R. (2015) Drought Adaptation and Coping Strategies among the Turkana Pastoralists of Northern Kenya. International Journal of Disaster Risk Science, 6, 295-309. https://doi.org/10.1007/s13753-015-0063-4

[2] Holzkämper, A., Calanca, P. and Fuhrer, J. (2011) Analyzing Climate Effects on Agriculture in Time and Space. Procedia Environmental Sciences, 3, 58-62. https://doi.org/10.1016/j.proenv.2011.02.011

[3] Malik, A., Fayyaz-ul-Hassan, Waheed, A., Qadir, G. and Asghar, R. (2006) Interactive Effects of Irrigation and Phosphorus on Green Gram (Vigna radiata L.). Pakistan Journal of Botany, 38, 1119-1126.

[4] Hanumantharao, B., Nair, R.M. and Nayyar, H. (2016) Salinity and High Temperature Tolerance in Mungbean [Vigna radiata (L.) Wilczek] from a Physiological Perspective. Frontiers in Plant Science, 7, 1-20. https://doi.org/10.3389/fpls.2016.00957

[5] SASOL Foundation (2014) Green Grams Hand Book [Internet]. Kitui.

[6] Yvonne, M., Richard, O., Solomon, S. and George, K. (2016) Farmer Perception and Adaptation Strategies on Climate Change in Lower Eastern Kenya: A Case of Finger Millet (Eleusine coracana (L.) Gaertn) Production. Journal of Agricultural Science, 8, 33-40. https://doi.org/10.5539/jas.v8n12p33

[7] Kihoro, J., Bosco, N.J. and Murage, H. (2013) Suitability Analysis for Rice Growing Sites Using a Multicriteria Evaluation and GIS Approach in Great Mwea Region, Kenya. SpringerPlus, 2, Article No. 265. https://doi.org/10.1186/2193-1801-2-265

[8] Halder, J.C. (2013) Land Suitability Assessment for Crop Cultivation by Using Remote Sensing and GIS. Journal of Geography and Geology, 5, 65-74. https://doi.org/10.5539/jgg.v5n3p65

[9] Ahmed, M. and Fayyaz-Ul-Hassana (2011) APSIM and DSSAT Models as Decision Support Tools. MODSIM 2011 19th International Congress on Modelling and Simulation-Sustaining Our Future: Understanding and Living with Uncertainty, Perth, 12-16 December 2011, 12-16.

[10] Jayasinghe, S.L., Kumar, L. and Sandamali, J. (2019) Assessment of Potential land Suitability for Tea (Camellia sinensis (L.) O. Kuntze) in Sri Lanka Using a Gis-Based Multi-Criteria Approach. Agriculture (Switzerland), 9, 148. https://doi.org/10.3390/agriculture9070148

[11] Kogo, B.K., Kumar, L., Koech, R. and Kariyawasam, C.S. (2019) Modelling Climate Suitability for Rainfed Maize Cultivation in Kenya Using a Maximum Entropy (MAXENT) Approach. Agronomy, 9, 727. https://doi.org/10.3390/agronomy9110727

[12] Wanyama, D., Mighty, M., Sim, S. and Koti, F. (2019) A Spatial Assessment of Land Suitability for Maize Farming in Kenya. Geocarto International, 1-18. https://doi.org/10.1080/10106049.2019.1648564

[13] Kamau, S.W., Kuria, D. and Gachari, M.K. (2015) Crop-Land Suitability Analysis Using GIS and Remote Sensing in Nyandarua County, Kenya. Journal of Environment and Earth Science, 5, 121-132.

[14] Mugo, J.W., Kariuki, P.C. and Musembi, D.K. (2016) Identification of Suitable Land for Green Gram Production Using GIS Based Analytical Hierarchy Process in Kitui County, Kenya. Journal of Remote Sensing \& GIS, 5, Article ID: 1000170. https://doi.org/10.4172/2469-4134.1000170 
[15] Mugo, J.W., Opijah, F.J., Ngaina, J., Karanja, F. and Mburu, M. (2020) Rainfall Variability under Present and Future Climate Scenarios Using the Rossby Center Bias-Corrected Regional Climate Model. American Journal of Climate Change, 9, 243-265. https://doi.org/10.4236/ajcc.2020.93016

[16] Njoka, J.T., Yanda, P., Maganga, F., Liwenga, E., Kateka, A., Henku, A., et al. (2016) Kenya: Country Situation Assessment. Res. Clim. Futur., Nairobi.

[17] Herrero, M., Ringler, C., Steeg, J., Van De, Koo, J. and Notenbaert, A. (2010) Climate Variability and Climate Change and Their Impacts on Kenya's Agricultural Sector. Nairobi.

[18] Endris, H.S., Omondi, P., Jain, S., Lennard, C., Hewitson, B., Chang'a, L., et al. (2013) Assessment of the Performance of CORDEX Regional Climate Models in Simulating East African Rainfall. Journal of Climate, 26, 8453-8475. https://doi.org/10.1175/JCLI-D-12-00708.1

[19] FAO (1976) A Framework for Land Evaluation: Soils Bulletin: 32. Food and Agriculture Organization of the United Nations, Rome.

[20] Gaiser, T. and Graef, F. (2001) Optimisation of a Parametric Land Evaluation Method for Cowpea and Pearl Millet Production in Semiarid Regions. Agronomie, 21, 705-712. https://doi.org/10.1051/agro:2001164

[21] Al-Mashreki, M.H., Akhir, J.B.M., Rahim, S.A., Kadderi, D.M., Tukimat, L. and Haider, A.R. (2011) Land Suitability Evaluation for Sorghum Crop in the Ibb Governorate, Republic of Yemen Using Remote Sensing and GIS Techniques. Australian Journal of Basic and Applied Sciences, 5, 359-368.

[22] Ogunwale, J.A., Olaniyan, J.O. and Aduloju, M.O. (2009) Suitability Evaluation of the University of Ilorin Farmland for Cowpea. Crop Research, 37, 34-39.

[23] Yohannes, H. and Soromessa, T. (2018) Land Suitability Assessment for Major Crops by Using GIS-Based Multi-Criteria Approach in Andit Tid Watershed, Ethiopia. Cogent Food \& Agriculture, 4, 1-28. https://doi.org/10.1080/23311932.2018.1470481

[24] Saaty, T.L. (2008) Decision Making with the Analytic Hierarchy Process. International Journal of Services Sciences, 1, 83-98. https://doi.org/10.1504/IJSSCI.2008.017590

[25] Meena, G.L., Singh, R.S., Meena, S., Meena, R.H. and Meena, R.S. (2014) Assessment of Land Suitability for Soybean (Glycine max) in Bundi District, Rajasthan. Agropedology, 24, 146-156.

[26] Grealish, G.A., Ringrose-Voase, A.B. and Fitzpatrick A. (2010) Soil Fertility Evaluation in Negara Brunei Darussalam. 19th World Congress of Soil Science, Soil Solutions for a Changing World, Brisbane, 1-6 August 2010, 121-124.

[27] Morton, F., Smith, R. and Poehlman, J. (1982) The Mungbean. 